\title{
Bjørnesund Project, West Greenland
}

\author{
Peter W. Uitterdijk Appel
}

The Bjørnesund Project is aimed at an evaluation of the mineral potential of the southernmost part of the municipality of Nuuk, between Bjørnesund and the large glacier Frederikshåb Isblink. One of the reasons that economic mineral deposits were expected to occur in the Bjørnesund area, was the presence of gold anomalies in heavy mineral concentrates from stream sediments (Appel, 1989). Another reason was the presence of anthophyllite-rich zones, presumed to have formed by hydrothermal alteration. At a fairly late stage in the planning of the field programme, the project was enlarged to include a regional geochemical stream sediment sampling programme in the area between $64^{\circ} \mathrm{N}$ and Bjørnesund. This latter part of the project was financed by a separate contribution from the Mineral Resources Administration, Ministry of Energy.

\section{Previous work}

In the $1960 \mathrm{~s}$ a geological reconnaissance mapping campaign carried out in the Fiskenæsset area revealed the presence of a $200 \mathrm{~km}$ long and, on average, $380 \mathrm{~m}$ wide stratiform anorthosite complex (Fig. 1). In the anorthosites chromite horizons were present, and subsequent studies showed some of the ultramafic horizons to be platinum-bearing (Ghisler, 1976). During the early geological investigations the Ravns Storø supracrustal belt was discovered, and at a later stage another extensive but rather thin supracrustal sequence was found in the Bjørnesund area.

During the 1970s GGU carried out a detailed mapping programme in the Fiskenæsset area (Fig. 1) (Kalsbeek, 1972; Kalsbeek \& Myers, 1973). This resulted in the publication of a set of coloured geological maps at a scale of 1:100 000 covering the area between Frederikshåb Isblink and Nuuk. Also during the seventies, Platinomino Aps., a subsidiary of the Canadian Renzy Mines Ltd., carried out mineral exploration in the Fiskenæsset area. This exploration was initially focused on platinum, copper and nickel in the stratiform anorthosites of the Fiskenæsset complex. Later, Platinomino's interests concentrated on rubies, which were prospected and sampled extensively throughout the region.
In the 1980s GGU carried out a geochemical sampling programme in the coastal part of the area. Heavy mineral concentrates from stream sediments were collected, checked for scheelite, and some of them were analysed for gold as well as for a number of other trace elements. One of the outcomes of this programme was the detection of gold anomalies in the Bjørnesund area, anomalies which originate from the supracrustal rocks (Appel, 1989). GGU also carried out investigations of the supracrustal rocks in the Nuuk area some $150 \mathrm{~km}$ north of Fiskenæsset. Here, investigations revealed zones which were interpreted as altered by hydrothermal brines, consisting of anthophyllite, in places with high amounts of sulphides and locally with tourmalinites (Appel, 1988). It was found that the supracrustal rocks in the Nuuk area contained significant scheelite mineralisation and were anomalous in copper and zinc (Appel, $1990 \mathrm{a}, \mathrm{b}, \mathrm{c})$. With this background it was decided to embark on a renewed investigation of the Bjørnesund and Ravns Storø supracrustal belts.

\section{Field work}

'Midgård', the former GGU base in Fiskenæsfjorden (Fig. 1) used in the 1970s, also served as base camp for the 1991 project. The six weeks' field work was supported by one helicopter and carried out by four geological field teams. The main targets of the project were as follows:

(1) Geochemical stream sediment sampling. This was carried out by two teams supported by helicopter. A total of 277 samples were collected, yielding a sampling density of one sample per $27 \mathrm{~km}^{2}$. A detailed sampling programme was carried out in the streams draining the two supracrustal belts, and locally lake sediments were also collected. At each site a silt geochemical sample and a water sample were collected, and radiometric readings were taken. All silt samples have been analysed for gold plus 34 other trace elements, and some of them also for platinum, palladium and base metals. The water samples were analysed for fluorine and uranium, and their conductivity was measured. 


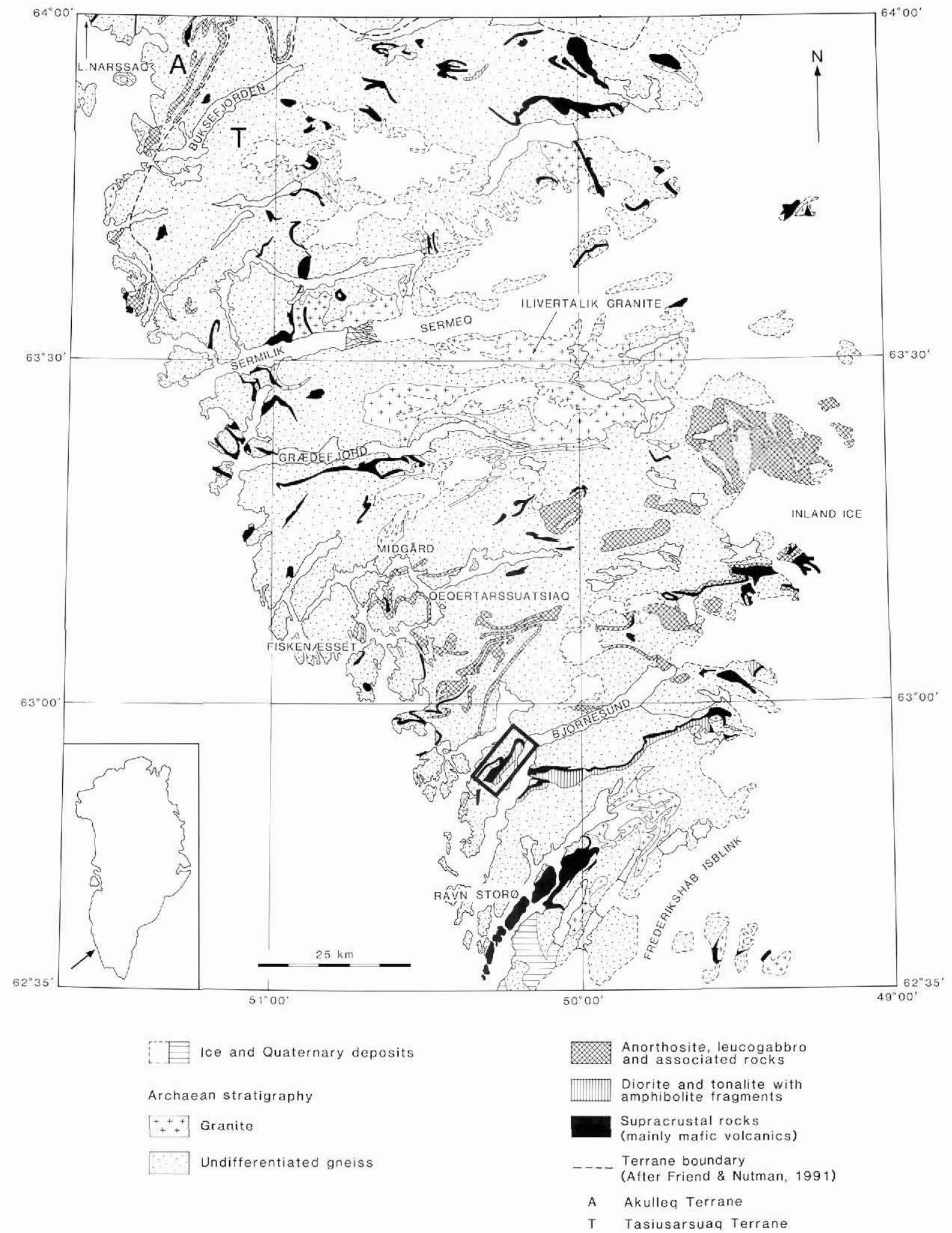

Fig. 1. Simplified geological map of the area between Frederikshăb Isblink and latitude $64^{\circ} \mathrm{N}$, based on GGU 1:500 000 geological map, sheet 2: Frederiksháb Isblink - Søndre Strømfjord. The supracrustal area on the north side of Bjørnesund is framed. 


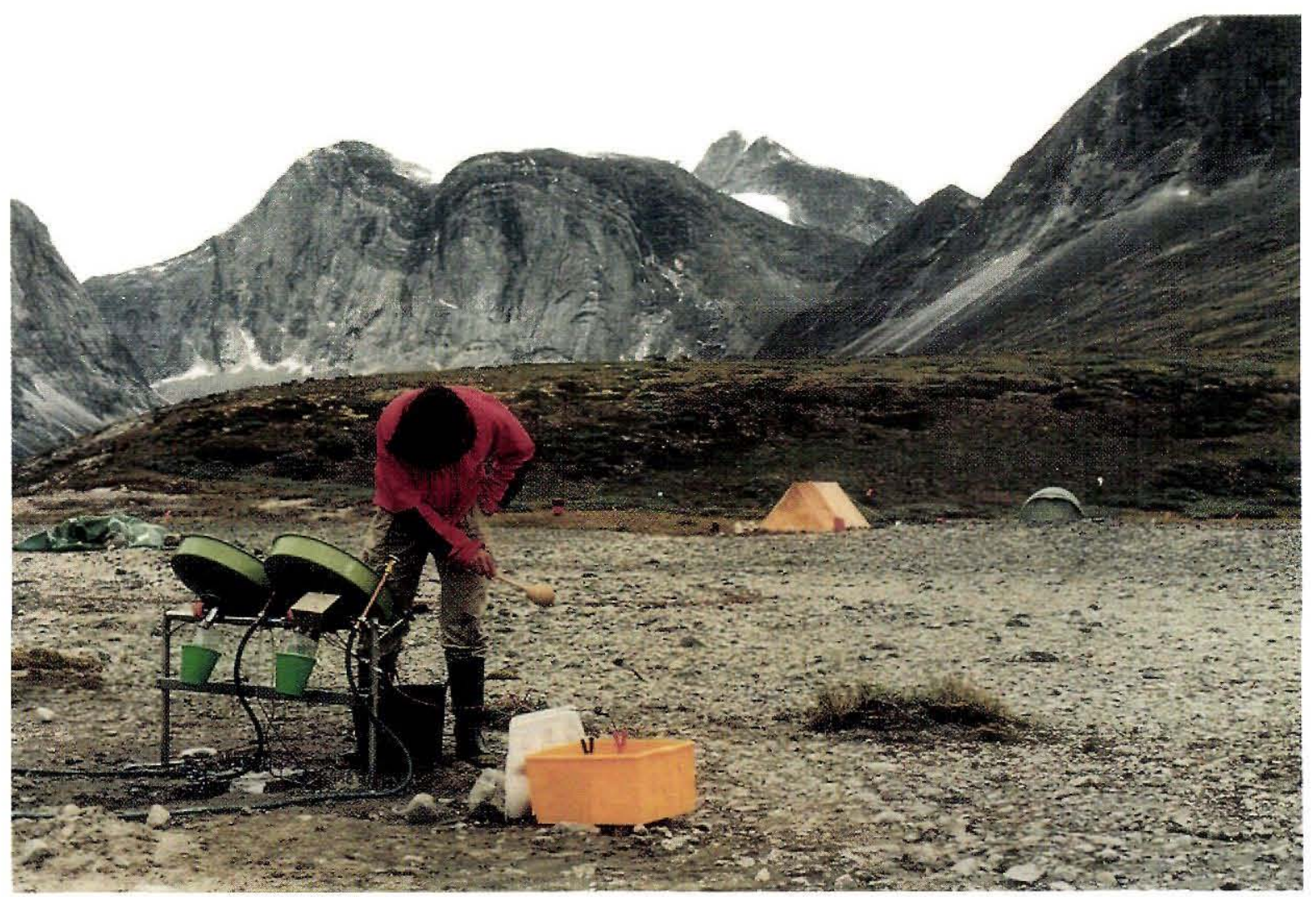

Fig. 2. 'Gold hound' processing heavy mineral concentrates from a large delta in the Bjørnesund area. Photo: M. Lind.

(2) Sampling of heavy mineral concentrates from stream sediments. This was carried out throughout the region, with a low sample density in the inland areas, and with a denser sample net in the Bjørnesund area. Most streams draining the Bjørnesund supracrustal rocks were sampled and the heavy minerals were concentrated in the base camp using a mechanical panning device (Fig. 2). The samples were subsequently analysed for the same elements as the silt samples.

In addition to the stream sediment sampling, bulk sampling and processing of gravels was undertaken from a large inland delta in the Bjørnesund area. This delta had yielded gold anomalies in heavy mineral concentrates during an earlier campaign (Appel, 1989).

(3) Investigation of supracrustal rocks. The Ravns Storø and the Bjørnesund supracrustal belts were investigated in some detail. Significant alteration zones were found in both supracrustal groups. Some of the alteration zones were anthophyllite-bearing with varying amounts of sulphides and locally with thin tourmalinites (Appel, 1992), whereas other zones were characterised by carbonate alteration, consisting of extensive replacement of the rocks by carbonate in hairline cracks, veinlets and veins. Some of the carbonate alteration zones are obvi- ously local whereas others occur in large scale shear zones, which cut gneisses as well as supracrustals. The different types of alteration zones were chip or channel sampled. These samples were subsequently analysed for gold plus 34 other trace elements, and most of them also for base metals.

(4) Ultrabasic rocks. In the area south of Bjørnesund two ultrabasic intrusive complexes were found, and a detailed map of them was made. In addition, a detailed chip and channel sampling programme was undertaken. It is as yet uncertain whether or not these ultrabasics are part of the Fiskenæsset anorthosite complex.

Although the Fiskenæsset complex was not the main target of the 1991 activities, a limited sampling programme was carried out in areas where Platinomino's exploration in the seventies had revealed platinum and/or gold anomalies. Chip and channel sampling was carried out across several ultramafic units, as well as across metre-wide shear zones cutting chromite layers. The latter shear zones were spectacularly stained by fuchsite and chrome epidote. The samples collected are being analysed for platinum, palladium and gold as well as for base metals. 


\section{Results}

Investigations on samples collected during the 1991 geochemical sampling programme have been published in GGU's Open File Report series (Erfurt et al., 1991). The geochemical analyses of the silt samples did not reveal any significant platinum or palladium anomalies, not even in samples collected in the immediate vicinity of the Fiskenæsset anorthosite complex. The rather few gold anomalies found during the regional geochemical sampling mostly originate from the supracrustal belts. Of particular interest, however, is a gold anomaly in a stream draining the part of the Bjørnesund supracrustal belt outcropping on the north side of Bjørnesund.

The analytical results from the heavy mineral sampling programme are also dealt with in an Open File Report (Erfurt et al., 1992). The rather few gold anomalies found mostly stem from supracrustal rocks. The two most anomalous samples, which contained 52 and 22 ppb gold respectively, are from two streams draining a supracrustal enclave situated on the north shore of Bjørnesund. Platinum anomalies are very few in the area. Of these a few can be ascribed to the Fiskenæsset anorthosite complex whereas other anomalies evidently stem from ultrabasic lenses situated in the supracrustal belts.

Bulk sampling of gravel in the inland delta carried out in order to test the possibility of placer deposits yielded disappointing results. No gold values above detection limit were found, and the heavy mineral concentrates from the bulk samples did not contain any other significant anomalies (Erfurt et al., 1992).

Some aspects of investigations of the two supracrustal belts are described elsewhere in this volume (Appel, 1992). Several rust zones and alteration zones found in the supracrustal rocks were chip and channel sampled. A major rust zone situated in the supracrustals on the north side of Bjørnesund (Fig. 1) was channel sampled, but with disappointing results, the best results being 11 ppb gold over $0.75 \mathrm{~m}$. In the same supracrustal enclave a grab sample of amphibolite with small amounts of pyrrhotite contained $172 \mathrm{ppb}$ gold. Ultrabasic lenses in the same supracrustal enclave appear to be the source of some of the gold and platinum anomalies noted in the heavy mineral sampling programme described above.

Carbonate alteration is widespread in the supracrustal rocks as hairline cracks filled with brownish carbonate, amounting locally to more than $25 \%$ of the rock. Chip sampling has been carried out across several carbonate altered zones. The best result obtained in the Bjørnesund supracrustal rocks is $52 \mathrm{ppb}$ gold over a width of $0.75 \mathrm{~m}$. In major shear zones cutting gneisses as well as supracrustals, carbonate alteration is a com- mon phenomena. Sampling of these large scale shear zones yielded up to $5.2 \mathrm{ppm}$ gold in a grab sample collected in the Bjørnesund supracrustal belt south of Bjørnesund.

The analytical programme on the chip and channel samples from prospective gold-platinum-bearing maficultramafic rocks in the Fiskenæsset anorthosite complex is underway. One of the best results on platinum group elements obtained so far is from a section of ultramafics, which yielded $0.11 \mathrm{ppm} \mathrm{Pt}$ and $0.48 \mathrm{ppm}$ Pd over 2 $\mathrm{m}$. The best gold values were obtained in a channel sample with $1.37 \mathrm{ppm} \mathrm{Au,} 4.6 \mathrm{ppm} \mathrm{Ag}$ and $0.27 \% \mathrm{Cu}$ over a width of $2 \mathrm{~m}$ in a somewhat rusty malachitestained sequence of carbonate-altered amphibolite at the contact with a large ultramafic body.

\section{References}

Appel, P. W. U. 1988: Stratiform tourmalinites in the Archaean tungsten province of West Greenland. Miner. Petrol. 39, 79-91.

Appel, P. W. U. 1989: Investigations of heavy mineral concentrates from stream sediment samples collected during the period 1982 to 1986 in the Nuuk area, West Greenland. Open File Ser. Grønlands geol. Unders. 89/1, 17 pp.

Appel, P. W. U. 1990a: Tungsten mineralization in the Nuuk region, West Greenland. Open File Ser. Gronlands geol. Unders. 90/4, $51 \mathrm{pp}$.

Appel, P. W. U. 1990b: Gold occurrences in supracrustal rocks of the Nuuk region, West Greenland. Open File Ser. Grønlands geol. Unders. 90/8, $21 \mathrm{pp}$.

Appel, P. W. U. 1990c: Copper, zinc and nickel occurrences in the Nuuk region, West Greenland. Open File Ser. Grønlands geol. Unders. 90/9, 28 pp.

Appel, P. W. U. 1992: Tourmalinites in supracrustal rocks in the Bjørnesund area, West Greenland. Rapp. Grønlands geol. Unders. 155 (this volume).

Erfurt, P. Steenfelt, A. \& Dam, E. 1991: Reconnaissance geochemical mapping of southern West Greenland from $62^{\circ} 30^{\prime} \mathrm{N}$ to $64^{\circ} 00^{\prime} \mathrm{N}-1991$ results. Open File Ser. Grønlands geol. Unders. 91/9, 21 pp.

Erfurt, P., Appel, P. W. U. \& Lind, M. 1992: Geochemical investigation of heavy mineral concentrates from stream sediments in southern West Greenland, $62^{\circ} 30^{\prime} \mathrm{N}$ to $64^{\circ} 00^{\prime} \mathrm{N}$ 1991 results. Open File Ser. Gronlands geol. Unders. 92/1, 39 pp.

Ghisler, M. 1976: The geology, mineralogy and geochemistry of the pre-orogenic Archaean stratiform chromite deposits at Fiskenaesset, West Greenland. Monogr. Series miner. Deposits, 14, $156 \mathrm{pp}$.

Kalsbeek, F. 1972: Field work in the Fiskenæsset area, southern West Greenland. Rapp. Grønlands geol. Unders. 45, 22-24.

Kalsbeek, F. \& Myers, J. S. 1973: The geology of the Fiskenæsset region. Rapp. Grønlands geol. Unders. 51, 5-18.

P. W. U. A., Geological Survey of Greenland, Copenhagen. 